\author{
Ke Sun Ке Сун \\ postgraduate student, National Academy of Fine Arts аспірант, Національна академія образотворчого \\ and Architecture of Ukraine мистецтва та архітектури України \\ тем. / tel: +380977735918 e-mail: A.Q.H@hotmail.com orcid.org/0000-0002-0029-5983
}

\title{
Unique Stylistic Features of Chinese Oil Painting: European influence
}

\author{
Унікамьні стимістичні риси \\ китайського омійного живопису: \\ Європейський вплив
}

\begin{abstract}
The article considers the processes that took place in Chinese oil painting under the influence of European traditions, which were brought to the territory of China due to the fact that Chinese artists of the twentieth century no longer wanted to remain limited to the ancient painting: they went abroad to study new techniques of painting and sought new creative ways.

After students returned to their homeland, they distributed new ideas, new methods they had mastered during the studies, which led to the emergence and development of unique stylistic features of Chinese painting.

It is pointed out that of the significant influence on the formation of the academic school, which was based on realistic style, were both the penetration of Western culture in the first half of the century and the introduction of the traditions of socialist realism from the USSR after 1949, which eventually gave way to the influences of other European styles on the art of China.
\end{abstract}

Keywords: China, oil painting, European influence, stylistic features, styles.

Problem statement. At the beginning of the $20^{\text {th }}$ century Chinese students studied painting in Japan and Europe, where modernism was widespread. Having received art education from renowned Western and Japanese professors, Chinese students gained a vast and diverse experience that allowed to diversify the traditions of realism with some features of Western modernism. After returning to the homeland, they tried to spread the acquired knowledge, skills and experience. Although there were many contradictions between realism and modernism, artists set themselves the goal: Western painting should change the Chinese one. During this period, the world of Chinese painting has become diverse and versatile. In 1937, after the end of the Sino-Japanese War, realism played a significant role in Chinese painting, mostly as a political propaganda. Realism strengthened its status by significantly pushing out the modernism, which temporarily shifted to the background. However, the influence of modernism on contemporary Chinese painting is no less important than the influence of realism, which, of course, makes it and the subsequent styles interesting issues for further research.

Analysis of recent research and publications. The range of problems dealt with in this article was considered by Fan Dian, Guan Liang, A. S. Panarin, A. I. Popov, M. Sullivan, Lu Xiaolou, Lin Fengmian, Ma Chang Li and others.
Their research is, of course, a solid, but not sufficient or exhaustive base to explain the influence of European art on Chinese art. Therefore, this problem requires further study and research.

Presentation of the main research material. Political changes in Europe throughout its history has always led to the emergence of new art styles and techniques. For example, neoclassicism in French art arose in the late $18^{\text {th }}$ and early $19^{\text {th }}$ centuries obviously due to the bourgeois revolution that happened in the same period. Scientific and industrial progress has also contributed to this process, so romanticism was directly related to the development of the Industrial Revolution in Great Britain. While impressionism arose as a result of inspiration by the scientific proof of the theory stating that a visible color in fact is a light reflected from an object. The modernism school of painting has set itself the goal of differing from traditional art styles. China had experienced a "new democratic" revolution at the beginning of the $20^{\text {th }}$ century as well, and was open to many new concepts and ideas. New disturbances arose in the world of art; artists were finding new approaches to inspiration and creativity. However, in a large number of cases, they were not 'exploring' western painting, rethinking the gained experience and knowledge, but rather only making use of the western artistic experience. Similarly, modern Western art contains many elements adopted from Oriental art. 
A well-known fact is that China and Europe already had a direct mutual trade by the beginning of the $18^{\text {th }}$ century, and hence porcelain, silk, Chinese paintings and other goods became popular among aristocrats in Europe at that time. Chinese goods became fashionable and of high demand due to high quality and artistic merits. As a result of the huge difference between the styles of the East and the West, many artists imitated Chinese works of art or incorporated oriental flavor to their works. For example, signs of Oriental art are strikingly evident in Antoine Watteau's The Embarkation for Cythera. Let us assume that Oriental art has had a significant impact on the development of European art, in particular the emergence and development of French post-Impressionism.

The issues of cultural interactions of the East and West are relevant and discussed even nowadays. The modern art market, which tries to combine globalization with growing interest in national peculiarities, puts new challenges to artists. A. Popov argues, "East and West should strive for mutual understanding and perception of the best from their cultures, including art" [1]. However, this problem has become relevant at least in the twentieth century, originating from even earlier time. Thus, A. Panarin, who considered the issue of globalism in its various aspects, believed that "the alternative to humanistic globalism may be re-synthesis of the experience of civilizations of the East and West" [2]. However, it can be argued that the process of such synthesis has been taking place in Chinese art since the beginning of the $20^{\text {th }}$ century, giving Chinese art more and more opportunities - from the appearance of nudes to pop art, photorealistic and interactive arts, etc.

In the twentieth century, most of the Chinese students who received education abroad, mainly in France and Japan, studied realism to compensate for the lack of certain techniques in Chinese painting and to adopt the advantages of Western Art. It was easier to study modernism, because the figurative language of this style of painting was clearer than of the other styles. It could be said that Japan was the first country to help China understand the Western style of modernist painting.

At the beginning of the $20^{\text {th }}$ century, thanks to convenient transport connections and relative geographical proximity, most of the abovementioned students studied fine arts in Japan at the Tokyo School of Fine Arts, or at the Kawabata School of Painting. Oil painting originated in Europe, and Japan was the first Asian country to adopt Western oil painting. All styles of contemporary western painting were presented in Japan at the beginning of the $20^{\text {th }}$ century. Among Japanese artists who have had a great influence on Chinese students, worth noting are Kuroda Seiki and Fujishima Takeshi, both artists and professors. They studied in Europe, and from their works it is clear they have added a bit of impressionism to a realistic base.

Chinese painter Guan Liang, who studied in Japan, wrote in Memoirs of Guan, "My teacher Nakamura Fusetsu, as well as the teacher of the Institute of Kawabata Fujishima Takeshi, and others were the next generation after Kuroda
Seiko, the founder of Japan's realism. On the one hand, the teacher demanded sustained basic skills of contour drawing from us, on the other hand, he tried to ensure that we sought not only for purely academic traditions. Anyone whose creativity would be just 'copying' would be deprived of the right to continue education. Under the guidance of these educators, the basis of realism was set as a combination of several components, including the Impressionist Revolution. Therefore, at that time I had an interest in impressionism and in its study as a separate style".

It is known that Japanese art of that time actively absorbed and assimilated European experience, the works of various genres of European art were regularly exhibited in Tokyo. These exhibitions helped both the Japanese and Chinese students to expand their horizons, to gain new knowledge in the arts. No doubt, they became a great source of inspiration. The works exhibited there belonged mainly to contemporary innovative styles of art (impressionism, post-impressionism, cubism, fauvism). Guan Liang emphasizes, "It did not quite correspond to what I was learning. In the vast pictures, in the unrestrained brush strokes I seem to have seen the imagination and will of the artists" [3]. The reason for this impression of the artist was the fact that during the study attention was focused mainly on the then official "academism", which predetermined certain limitations in art. This provoked the desire and efforts of the artists to free themselves, to leave the studios in favor of the streets, in order to make full use of their abilities, to embody the gained artistic experience in works that would have the desired power of light and color. As we see, in the early twentieth century, most of the Chinese artists who studied in Japan were adherents of the Japanese ideas of oil painting. They took realism as a basis, and added to it the technique of impressionism [3-5].

Chinese artists who studied Western painting in Europe and Japan had a general tendency to be rather adherent to realism, but those who studied in Japan more often turned to modernism. Liu Xiaolou notes that the creative work of artists who studied in Europe can be divided into two periods [3]. The early period is represented by the work of Lin Fengmian, who headed the Beijing School of Fine Arts (1925-1927) and was the representative of the Hangzhou National Academy of Arts (1928-1937). He tolerated various schools of Western painting. That late period is represented by works by Xu Beihong, graduate of the Central University and of the Beiping Art School. Realism was his only style.

Japanese oil painting does not have such a long tradition of academic education as the European one. Initially, some influence was made by, actually not widely accepted, European plein air painting, followed by Western modernism. Considering how Chinese students were making their choice whether to study in Japan or in Europe, it should be noted that Japanese students had already adopted Western modernism, which led to transformations in the creative minds of the Chinese artists as well. Before 1937, most Chinese students had been choosing to study in Japan. At that time, various schools of contemporary western painting had already 


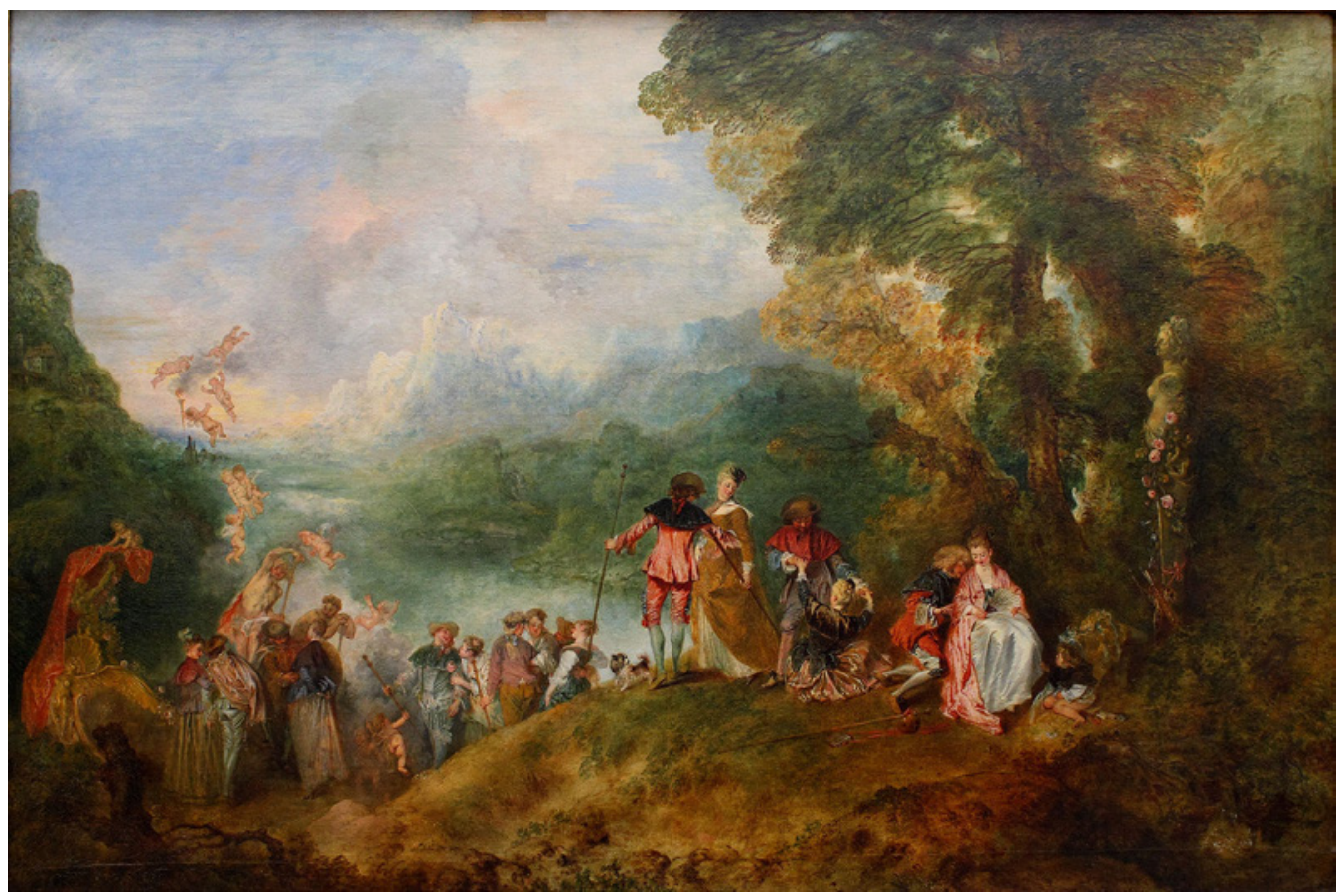

Antoine Watteau. The Embarkation for Cythera. 1717. Oil on canvas. $129 \times 194 \mathrm{~cm}$. Louvre

reached Japan, and that variety of genres that flooded Japan determined a new period in the history of Japanese art. That was a period of discoveries, a period of many different styles of painting. Because of, to some extent common, oriental mentality of Chinese and Japanese artists, they found a lot of points of contact, which resulted in a powerful creative outbreak. According to Liu Xiaolu, even the names of styles were first translated into Chinese in Japan, "Many of the concepts of contemporary Western art were first written in Chinese hieroglyphs by Japanese, and then brought to China by Chinese students: impressionism, post-impressionism, neo-impressionism, dadaism, fauvism, expressionism, abstractionism, cubism, surrealism, etc." [3]. Summing up, it should be noted that the development and spread of contemporary art in China is largely the achievement of Japan and Chinese students who studied there.

Considering a large part of the works of the $20^{\text {th }}$ century artists who studied painting in Japan, one can see that many of them used the styles studied there, including impressionism and fauvism. For example, Li Shu-Tong (1880-1942), who traveled to Japan in 1905 at his own expense. Kuroda Seiki became his tutor. Long before joining the School of Fine Arts, he was keen on Kuroda Seiki's work, devoting a lot of time to study his paintings, so the impressionism of Seiki strongly influenced the style of Li Shu-Tong's oil painting. Li Shu-Tong created the painting The Half-Naked Woman when he was a student. Nude nature was the main subject of Japanese oil painting during that period, which was the result of a boycott of traditional art and internal resistance to outdated norms and dogmas. It was happening as a result of cultural revival and awareness of the need to expand the cultural boundaries, to use the ideology of Western painting.

Kuroda Seiki often portrayed naked women without a background, his triptych Wisdom, Impression, Sentimentality is a work of that kind. Li Shu-Tong imitated and repeated the manner of Kuroda, creating pictures of the same subject of a naked body. As for the technique and composition, this work has rather obvious similarities with another masterpiece by Kuroda Seiki-The Girl Sitting on a Chair. When comparing them, we should note that the expressions of the faces of the characters are invulnerable, the image and composition are precisely balanced, variations of light and color are also worth the attention. Therefore, it should be emphasized once again that the impressionism of Kuroda Seiki influenced the style of Li Shu-Tong oil painting, which is quite a typical situation within the process of the mastery of the Japanese painting by Chinese artists. Such processes took place not only between teachers and students, but also due to participation of students in the cultural life of Japan, as they were visiting exhibitions, studying works of art of famous Japanese artists, communicating with them, etc.

Guan Liang (1900-1986), who went to Japan in 1917 to study painting, returned to his homeland in 1923, where he became a professor at the Shanghai Art College. Guan Liang's works are an integral part of contemporary Chinese art, and perhaps he was the first who introduced the ideas of Western modernist painting to the traditional Chinese ink painting. He created unique theatrical portraits and had a high reputation both at home and abroad. The influence of modernism is tangible in his paintings. Not only his techniques were appropriate to the style, but the theories and ideas as well. Speaking about ways to understand contemporary art, Guan Liang emphasized the following, "Intimate knowledge of the theory and comprehension of the spirit of contemporary painting will enable us to understand why not to poison this kind of art. Artists should have appropriate education, especially at present, otherwise they are just artisans" [3]. This statement accurately illustrates the academic background of the time, it was a mild criticism of some 
not very talented artists active in contemporary art. Guan Liang not only had a good education, but was also immersed in the world of art, which was reflected in his paintings.

Guan Liang had his own painting style, which was distinguished by the charming pointillism of the lines, combined with a deep understanding of traditional Chinese painting he revealed in his works. The characters of the Beijing Opera, he depicted in his last years, have not only pronounced characters, but also the special original individuality inherent in Chinese art since the early stages of its formation.

The allusion to Henry Matisse's fauvism is evident in Guan Liang's After Bath and Still Life on the Table. Matisse believed that art has two forms of expression, one answers the question "how it is depicted", and the other is "how it is expressed". He stood for the last one. Later Matisse, in the process of studying Oriental art, has transformed his struggle for dynamic, productive painting, unrestricted in its opinion, into search of balance, a sense of purity and tranquility. One can say that due to the Eastern art, the great master discovered many new graphic methods, he realized that the picture is a scenery. On the contrary, Guan Liang turned the scenery into his painting.

Thus, the western style of painting penetrated into China through education, exhibitions, magazines and in other ways: it was a conscious amalgamation of the local culture with the global one. The purpose of this process was to formulate the classical style by adoption of certain features and phenomena from the styles of other countries, which was important for the Chinese oil painting of the twentieth century. This style embraced some of the elements of classical painting along with slight changes in light and color, as well as a subjective view of the depicted object. That was a way to paint still lifes, landscapes and portraits. Such works of art were a good basis for Chinese contemporary painting. There began to appear works, which represented the Chinese style of painting, its image. It is also necessary to note the true evolution of the techniques that became the object of further research and served the identification of works. The latter activities became a very important task of contemporary Chinese painting and art studies.

A significant part of the Chinese students, mostly those who worked in the style of modernism, or used its elements, studied in France. For example, Zhang Yu (1900-1966), Ya Yu (1903-1988), Lin Fengmian (1900-1999). Among them, Lin Fengmian is considered the typical exponent of this style. He was a pioneer in contemporary Chinese painting. Lin Fengmian, during his studies in France, got acquainted and later became friends with the famous artist Fernand Cormon. Though Cormon was a typical representative of classicism, it did not force Lin Fengmian to study European classicism. Thus, the transformation of Chinese painting took place due to the conviction of the leading Chinese artists of that time in the need for change, and through the study of stylistic features of the best examples of European art by those artists.

As we know, different groups and unions appeared there, such as: "Oriental art”, "Pegasus", "Apollo-Soyuz", "Art movement", "Decisive wave" and others. The artists created unions, held exhibitions, their purpose was cultural exchange of the East and West, as well as the spread of Western painting. Of all these groups, the "Decisive wave" was the most typical, most of its members were young artists, whose creative work was strongly influenced either by the impressionists or their contemporaries. Pan Sung Chen (1906-1985) was the founder of the group. He studied in France, where he has undergone a profound influence of European modernism. During his study, Katz, a Polish artist and friend of Manet, once said, "You spend so much time copying, you could also use your mind, while copying can only give skills, improve techniques, there are so many masterpieces in the Louvre, will you have the time to copy them all?" [6].

Pan Sung Chen gradually began to realize that pure copying, or imitation, would never be able to yield a true work of art, and copying-based works would never be appreciated. He started trying different styles and seeking for a new artistic path. Pan Sung Chen's paintings were not limited to the imitation of Western painting, on the contrary, he was constantly looking for his own way to participate in the transformation of Chinese painting. The ideas of "harmonious coexistence of oriental and western art" were followed not only by Pan Sung Chen, but also by all other members of the "Decisive Wave" group.

We can assume that this group was a community of spiritually united of rebellious artists, although they did not share a common artistic idea. That kind of unity encouraged artists to explore the western artistic trends. They were creating a living culture of art. They did not simply copy or imitate Western painting, but had studied it well first, and then, having the common goal of changing Chinese traditional painting, created their own new forms of expression, which became the basis for the new art of China.

To understand Western modernism, Chinese artists should first understand the essence of Oriental art, its quintessence and its limits. In 1935, the "Crisis Wave" group self-dismissed for political reasons, in particular due to the war and economic difficulties. However, many enthusiastic and rebellious artists remained in China.

In total, during the five years of the group's activity, four exhibitions were held. The exhibitions were full of freshness Chinese young art; the purpose of exhibitors was also very clear and constructive. However, they did not take into account all aspects of the situation of that time, as China has not yet matured for a look into the future. The main mistake of young artists was not taking into account the ignorance of the new mood and aesthetic feelings of the artists by the government, which led its own cultural policy. Similarly, the artists themselves were partially distanced from their nation. It should be noted that most of the people of China were not ready to accept art of modernism at that time, so realism managed to monopolize artistic world.

Let us analyze the main factors influencing the work of Chinese oil painters on the example of the creative ways of Ma Chang Li and Ma Lou. Father and son, they are rep- 
resentatives of two consequent generations of Chinese artists. Both were teachers at China's leading artistic higher education institution, the Central Academy of Arts of China, which was established more than a hundred years ago. We will trace the evolution of the European traditions of painting in Chinese art, which will further enable us to formulate the principles of the formation of contemporary Chinese fine art.

Ma Chang Li was born in 1931. In 1963, he graduated from the Central Academy of Fine Arts of China. At that time, the Academy became the center from which the European traditions were being spread to Chinese artistic education. The supervisor of Ma Chang Li was Lu Gun Liu (19162004), who studied in the USSR in 1955-1958, his teachers being B. V. Johansson and V.M. Oreshnikov. During his studies he copied the painting of French impressionists in the museums of Leningrad and Moscow. An interesting fact is that he made a creative trip to Ukraine with his groupmates from China. In Ukraine, he painted the Black Sea landscapes, creatively developing the themes of Ukrainian rural life.

Upon his return to China he was appointed deputy rector of the Central Academy in the rank of professor and head of the educational studio. The area of research of the studio was Soviet painting and impressionism. Therefore, much attention was paid to the plein air itself. Let us note the critical attitude of Luo Hun Liu to the system of Soviet artistic education. In his opinion, artists lost their subjectivity in the reproduction of the image as a result of uniformity of their creative methods. He considered it necessary to unite European and Chinese paintings, in particular, European impressionism and Chinese style.

Study and experiments did not stop for Ma Chang Li after graduation from the Central Academy. He continued to persevere in exploring oil painting. Ma Chang Li believes that the main thing is to find the occasion for creative work in everyday ordinary life. For example, depiction of the mountains is an interesting task in both traditional and contemporary Chinese painting. Yet, in his opinion, human life in all its manifestations is much more interesting than the life of nature. Ma Chang Li traveled in different provinces of China, covering the natural and cultural aspects of the West, the South, and the North. He painted a lot on the plein air. He believed that in the north, the sky and its color were important in the landscape, while in the south it was not so important, because of often mist. He deemed creation, by observing nature, of a work that would reflect the impression and feel of the artist was his main aim. After all, in his opinion it was exactly the way to reproduce and the depth of the motive and to bring it to the viewer.

Ma Chang Li reveals his feelings by means of color. He successfully solves one of the main tasks of oil painting, namely the transfer of emotional perception of the artist to the viewer by means of painting. Of great importance in his oil painting is the voluminosity, or the texture of paints. Ma Chang Li believes that in oil painting the light tone is not as important as the color, while in ink painting, the most im- portant are tonal gradations. Ma Chang Li states, "My work combines impressionism and the oriental style of 'xieyi'. I want to show people the color and texture of oil painting" [7].

Renowned art historian, rector of Central Academy of Fine Arts of China, Fan Dian believes that landscape painting of Ma Chang Li has three most important features as follows:

First, the artist really depicts nature and life so that the viewer feels the air, the reality of the landscape. His landscapes are always material, have a deep illusory perspective, so that the effect of monumentality and epics is achieved.

Secondly, many years of experience in the search for sceneries makes the artist able to reproduce the most characteristic features of different places and natural landscapes.

Thirdly, his landscape compositions are full of artistic findings and discoveries. The artist finds something proper between pure realism and abstract expressionism [8].

It should be noted that a very vigorous stoke, a sense of rhythm, texture of the canvas surface is very typical for $\mathrm{Ma}$ Chang Li's paintings. The rhythm and motion which are present in all of his paintings indicate a rejection of the classical motionless, rather still, images. Here we can see the movement of trees in the wind, and the mysterious spiral-like rhythms of the mountain ranges, and the versatility, variability of the landscape. The dynamics of perspective and landscape is very important for the artist. That is why what is depicted looks very vital, and at the same time generalized.

So, in his well-known painting On the Pasture, where Tibetan women with mortars are depicted on the background of a blue sky with white clouds, everything is subordinated to a common rhythm. In general, this is a genre scene where shepherds' wives are crushing grasses in mortars to prepare a traditional tea. Yet the artist rendered it to a truly cosmic scale. In order to show the interaction of human and nature, he gave silhouettes of female figures some bizarre shapes, which repeat the rhythm of the clouds. Everything in the picture is permeated with the general circulation of motion, with natural energy. Undoubtedly, many years of experience in plein air painting helped the artist to achieve the truthfulness and figurativeness.

Ma Lou was born in Beijing in 1958. From 1982 to 1984 he studied in Germany, at the University of Arts of Hamburg. In 1984, he returned to China and began teaching. Ma Lou was a participant of the All-China Exhibition Nude Nature, which took place at the Central State Art Museum of China in 1988. Then he almost completely abandoned figurative painting in favor of abstract compositions. He is currently the Head of the Faculty of oil painting in China Central Academy of Fine Arts.

He believes easel painting in the future should evolve, moving from classical forms to something new, because the clear division of painting into oil painting, watercolor, etc. by techniques is restraining and limiting the creativity of artists. In the history of classical painting, both in Europe and in China, the tempera and fresco techniques, as well as encaustic played a huge role. 
He considers drawing as the basis for painting, not in the sense of academic skills, but as instant means of expression of thoughts, rhythms, and lines. In this, he, like his father, acts as a follower of the "xieyi" (also known as "shuimo", which means "ink and wash painting") style, which primarily reveals the artist's idea. For Ma Lou, the feelings of the artist and his philosophical outlook are much more important than the very picturesque qualities of the painting. The point is not to convince the jury at the exhibition, but to have his own opinion and idea. He teaches his students that all artists have the right for their own point of view $[9 ; 10]$.

In his paintings, he simultaneously practices oil and acrylic painting. Such experiments help him to expand the range of artistic self-expression. Paintings of Ma Lou, of course, can be regarded as pure abstract art, however, the viewers associate his paintings with landscape motifs. In our opinion, this confirms that the author is able to achieve a certain natural harmony through the use of dynamic contrasts between the main compositional masses, and sometimes on the contrary by maximizing the generalization of the shapes and tints. The most important thing is that the artist presents on canvases not just paints, but also his feelings, which are expressed that much skillfully they simply cannot leave the viewers indifferent.

Therefore, on the example of the father and son of $\mathrm{Ma}$ Chang $\mathrm{Li}$ and $\mathrm{Ma}$ Lou, we traced some significant aspects of the creative ideas and beliefs of Chinese artists who interpreted European traditions in their work. As we see, the desire to create a new artistic language, which would manifest the underlying aspirations of the Chinese mentality and would have a contemporary and relevant perception were the main tasks the artists solved in their work. The relationship, as well as the same alma mater-Central Academy of Arts of China-certainly makes the creativity of these two representatives of different generations quite similar. However, it is they who allow us to feel the main tendencies that have been transforming Chinese modern painting during the $20^{\text {th }}-21^{\text {st }}$ centuries.

\section{References}

1. Popov A.I. Vzaimodeystvie tsennostey zapadnoy i Vostochnoy hudozhestvennyih kultur - ob'ektivnaya neobhodimost sovremennogo tsivilizatsionnogo protsessa // Analitika kulturologii. 2006. \#2.

2. Panarin A.S. Iskushenie globalizmom. Moskva: EKSMO, 2003. $256 \mathrm{~s}$.

3. Lu Siaolu. U kazhdogo svoy put: v pamyat o pionerah sovremennogo kitayskogo iskusstva, obuchavshihsya v Vostochnoy Azii i na Zapade. Pekin, 2004. $126 \mathrm{~s}$.

4. 刘淳 《中国油画史》中国青年出版社 2005 年7月 第44页 [Liu Wei. The History of Chinese Oil Painting / / China Youth Press. July 2005. p. 44.] 5. 刘淳 《中国油画史》中国青年出版社 2005 年7月第97页 [Liu Wei. The History of Chinese Oil Painting // China Youth Press. July 2005. p. 97.$]$ 6. Sullivan M. Art and Artists of Twentieth-Century. China. Berkeley, Los Angeles: Ahmanson Murphy Imprint in Fine Arts, 1996. 392 p.

7. 《满幅晹律总关情一马常利先生的油画艺术》范迪安 发表于《中国文化报》
It should be noted that Ma Lou, following in his father's steps, visited Ukraine twice and exhibited his painting to a local audience, held interesting discussions with colleagues by artists and teachers. In particular, he was very interested in Ukrainian sacred art and was impressed by the creativity of the Boychukists, who were previously unknown to him. This confirms once again that true art has no boundaries. In the future, he plans to implement a monumental project together with Ukrainian artists.

Conclusions. To sum up, we will emphasize once again that in the early twentieth century Chinese artists did not want to keep to the beaten track of the ancient traditional painting anymore, so they were going abroad to study western painting. After returning home, they divided into two groups, namely, the realists and the modernists. These very groups have formed the basis of Chinese painting style of that time. Chinese artists who studied modernism had understood its essence and wanted to bring it to China, because they were convinced the traditional Chinese painting could be changed with the help of modernism. However, many mentors said Chinese students should first comprehend the essence of almost a thousand year long history of painting in their own country. Despite all the historical, educational and social circumstances of the time, most of the ideas of modernist and avant-garde artists had the right to life. Nevertheless, they did not take the situation in China thoroughly enough. The beginning of the twentieth century was a turbulent era, when numerous social, political and other reasons, combined with deep-rooted conservative aesthetic views of the Chinese people, did not allow modernism to take a worthy place on the world cultural map. Realism, strongly supported by the Chinese government shortly after, was more appropriate and acceptable to China by then.

Thus, Chinese artists of all the creative areas have made efforts to bring the latest global tendencies in Chinese painting. Regardless of whether they were representatives of realism or modernism, they all postulated that "Western painting would help to change Chinese traditional painting." This concept has been influencing the creative spirit of Chinese artists since the twentieth century up to now.

\section{Мітература}

1. Попов А.И. Взаимодействие ценностей западной и восточной художественных культур - объективная необходимость современного цивилизационного процесса// Аналитика культурологии. 2006. № 2. С. 53-57.

2. Панарин А.С. Искушение глобализмом. Москва: ЭКСМО, 2003. $256 \mathrm{c}$.

3. Lu Siaolu. U kazhdogo svoy put: v pamyat o pionerah sovremennogo kitayskogo iskusstva, obuchavshihsya v Vostochnoy Azii i na Zapade. Pekin, 2004. $126 \mathrm{~s}$.

4. 刘淳 《中国油画史》中国青年出版社 2005 年7月 第44页 [Liu Wei. The History of Chinese Oil Painting // China Youth Press. July 2005. p. 44.] 5. 刘淳 《中国油画史》中国青年出版社 2005 年7月第97页 [Liu Wei. The History of Chinese Oil Painting // China Youth Press. July 2005. p. 97.] 6. Sullivan M. Art and Artists of Twentieth-Century. China. Berkeley, Los Angeles: Ahmanson Murphy Imprint in Fine Arts, 1996. 392 p. 
[Full rhythm of the general relationship: oil painting «Fan Dian» by Ma Chang Li / / Chinese News of Culture. 12/13/2015]

8. Fan Dian. Chinese Fine Arts in the 1990's. 1993. 160 p.

9. Fan Dian. Ten Noted Contemporary Chinese Oil Painters and Their Artistry. Fuzhou: Fujian Fine Arts Press, 1994.

10. Fan Dian, Leng Lin, and van Dijk H. Ideals and Idols of Beijing (catalog). Hong Kong: Schoeni Art Gallery, 1994. 95 p.
7. 《满幅韵律总关情一马常利先生的油画艺术》范迪安 发表于《中国文化报》 [Full rhythm of the general relationship: oil painting «Fan Dian» by Ma Chang Li / / Chinese News of Culture. 12/13/2015]

8. Fan Dian. Chinese Fine Arts in the 1990's. 1993. 160 p.

9. Fan Dian. Ten Noted Contemporary Chinese Oil Painters and Their Artistry. Fuzhou: Fujian Fine Arts Press, 1994.

10. Fan Dian, Leng Lin, and van Dijk H. Ideals and Idols of Beijing (catalog). Hong Kong: Schoeni Art Gallery, 1994. 95 p.

\section{Ке Сун}

Унікальні стилістичні риси китайського олійного живопису: Європейський вплив

Анотація. У статті розглянуто процеси, які відбувалися в китайському олійному живописі піА впливом європейської традиції, принесеної на територію Китаю у ХХ столітті. Китайські митці початку століття більше не хотіли мишатися обмеженими давнім живописом: вони вирушали закордон, аби опанувати нові техніки живопису та віАнайти нові шляхи творчості.

Після повернення на батьківщину студенти поширювали нові ідеї та методи набуті піА час навчання, що спричинило появу та розвиток унікальних стилістичних особливостей китайського живопису.

Наголошено, що суттєвий вплив на формування академічної школи, заснованої на реалістичному стилі, справило як проникнення захіАної культури в першій половині сторіччя, так і знайомство із соціалістичним реалізмом із СРСР (після 1949 року), що зрештою віАкрило шиях впливам інших європейських стилів на мистецтво Китаю.

Ключові слова: Китай, олійний живопис, європейський вплив, стилістичні риси, стилі.

\section{Ке Сун}

Уникамьные стимистические особенности китайской масляной живописи: Европейское вАияние

Аннотация. В статье рассмотрены процессы, происходившие в китайской масмяной живописи поА влиянием европейских траАиций, привнесённых на территорию Китая вследствие того факта, что китайские художники Авадцатого века более не желали быть ограниченными традиционной живописью: они ехали за границу, чтобы изучить новые живописные техники и искали новых творческих путей.

После возвращения на родину они распространяли новые идеи и методы, освоенные во время учёбы, что привело к появлению уникальных стилистических особенностей китайской живописи.

Подчеркивается, что значительное влияние на формирование академической школы, базировавшейся на реалистическом стиле, оказало как проникновение западной культуры в первой половине века, так и знакомство с традициями социалистического реализма из СССР (после 1949 гоАа), что в послеАствии открыло путь влиянию Аругих европейских стилей на искусство Китая. Ключевые слова: Китай, масляная живопись, европейское вмияние, стилистические особенности, стили. 